\title{
Victorian Literature and the Variety of Religious Forms
}

Literary Studies is not the only discipline to show a new enthusiasm for religion in the opening decades of the twenty-first century. When Stanley Fish suggested back in 2005 that religion might become the new theoretical center of gravity in the humanities, his declaration was cited frequently and may have proved a little too convenient for those, like myself, who wanted to see a major theoretical realignment in the humanities' attitude to religion. ${ }^{1}$ But the reality is that Fish was just one of a number of other prominent theorists in the last twenty years or so to have shown a new appreciation for the theoretical resources that religious thought makes available. Although the term religion is understood very differently across thinkers such as Giorgio Agamben, Judith Butler, Jacques Derrida, Bruno Latour, Sabo Mahmood, Charles Taylor, and Slavoj Zizek, they share a refusal to accept crude notions of the secularization thesis, with its commitment to seeing religion as an irrelevance in the modern world, and are instead determined to see religion as more than just an antiquated ideology that needs to be unmasked.

The consequences of this religion turn can be seen in recent studies of the Victorian period, and the proliferation of new work in this area stands in marked contrast to the second half of the twentieth century, when religion seemed to be of marginal interest to the majority of literary scholars writing about Victorian literature. There were prominent exceptions, of course, including Valentine 
Cunningham (1975), Elisabeth Jay (1979), George Landow (1980), G. B. Tennyson (1981). Stephen Prickett (1986), Christine Krueger (1992), John Maynard (1993), Michael Ragussis (1995), and Ellis Hanson (1997). But for the most part, the topic of religion was left on the sidelines. When it was taken up and discussed, it was often situated in a narrative about the loss of belief and the inevitable decline of an older sphere of thought in the modern world. Consider, for instance, the pointed title of J. Hillis Miller's influential study, The Disappearance of God (1963), or the regularity with which scholars in the 1960s, 1970s and 1980s framed Victorian debates about religion in terms of faith and doubt. The faith and doubt paradigm positioned belief in the Christian religion as the losing side in a battle with modern skepticism, and the stories told were typically ones in which faith gave way to a doubt deemed more credible and more modern. ${ }^{2}$ Given how the paradigm made the story of faith's decline inevitable and predictable, it was unsurprising when few scholars writing in the 1980 and the 1990s showed much constructive interest in the subject of Victorian religion.

This was the context in which I started out as a scholar of nineteenth-century literature, and, with Emma Mason, found myself mourning the absence of a book that might help those who were largely ignorant of the Christian religion familiarize themselves with some of its basic details. The two of us were not completely without resources: in addition to the work of the literary scholars mentioned already, we were grateful for the contribution of religious historians such as David Bebbington, 
Boyd Hilton and Frank M. Turner. But the lack of a short single-volume introductory work on religion and Victorian literature, designed primarily for those in the discipline of literary studies, led to the two of us writing Nineteenth-Century Religion and Literature: An Introduction (2006). We were not alone in feeling that religion needed more attention. The opening years of the twenty-first century saw Victorian Literature and Culture produce a 2003 special issue on the topic of Victorian Religion, and the sense that attitudes to religion were changing received further support from exciting new books by Frederick S. Roden (2002), Carolyn W. de la L. Oulton (2003), and John Schad (2004). By the time our book appeared in 2006, it found itself among a cluster of other major works published around the same time, including Colin Jager, The Book of God: Secularization and Design in the Romantic Era (2006), Patrick R. O'Malley, Catholicism, Sexual Deviance and Victorian Gothic Culture (2006), William McKelvy's The English Cult of Literature: Devoted Readers, 1774-188o (2007), Nadia Valman, The Jewess in Nineteenth-Century British Literary Culture, (2007), and Michael Wheeler, The Old Enemies: Catholic and Protestant in Nineteenth-Century English Culture (2007).

This article aims to review some of the important works that have appeared over the subsequent decade, from 2008 to 2017. In the interests of space, I have avoided books that deal with atheism, agnosticism, and the occult. I recognize their overlap with the subject of my essay, however, and am aware that more than a few scholars consider these areas to be just as "religious" as traditions such as 
Christianity and Judaism. One of the many benefits of the turn to religion in our scholarship on Victorian literature has been greater recognition of the different views we hold about what the term religion means. This methodological diversity is to be expected: not only does it reflect major debates in the second half of the nineteenth century as to whether religion was best understood in the academy or in faith communities, but the differences among contemporary literary scholars also echo long standing debates in the discipline of Religious Studies. For some of those working in Religious Studies, religion should be understood functionally, with activities and rituals deserving the description religious if they fulfill the same sort of spiritual, social and ethical functions that might once have been consider the preserve of the church. Another group of scholars who write about religion still prefer to think of religion as requiring a substantive belief in the numinous or some sort of divine supernatural being. Others, following Friedrich Schleiermacher, see religion as a feeling, a "sense and taste for the infinite," and resist the call for a more precise definition. And another group prefer to think more historically, with the influential sociologist of religion Danièle Hervieu-Léger, to take one prominent example, describing religion as a chain of memory, a series of signifying acts by which individual believers are connected in time through shared traditions and ideas.

While the methodological questions that surround these various uses of the term religion deserve proper consideration, they need not function as a roadblock to 
those in literary studies who want to engage meaningfully with the topic. Literary scholars regularly and deliberately use language without fully understanding what our words mean, and at the risk of disciplinary simplification, we are a group of people who are well placed to see how the meaning of religious language is defined as it is used rather than being determined in advance. In this respect, we might well want to take inspiration from Michael Wheeler's more localized observation in St John and the Victorians that "what some Victorian commentators recognized, and some poets and novelists exploited, was the paradox that it was only in the very breakdown of language and in the silences of the narrative that the possibility of faith opened up."3

The different understandings of religion that operate throughout the books under discussion here offer an additional benefit for those who remain nervous of talking about religion, for they guard against a re-inscription of the ideological violence that some scholars continue to associate with the three Abrahamic religions. In the late-twentieth century, scholarly concern with power and ideology rendered nineteenth-century Christianity the site of considerable suspicion. The proximity of the Christian faith to the concerns of the state seemed evident in a national Anglican church that appeared to be too caught up with the pursuit of power and influence, and the problem of Christianity's collusion with the state was readily apparent in the work of Imperial Britain. There are significant problems with this collusion with the state, that continue to require our attention, but recent 
scholarship has helped us see that Christianity is less monolithic than this line of thought might presume. Caroline Levine's work in Forms: Whole, Rhythm, Hierarchy, Network (2015) offers a helpful insight as to why we might want to think about the different forms of religion that existed in the nineteenth century, even though religion is not her primary area of focus. Her emphasis on "social disorganization, exploring the many ways in which multiple forms of order, sometimes the results of the same powerful ideological formation, may unsettle one another," can be extended to our thought about the Christian religion in Victorian literary culture. ${ }^{4}$

At a basic level, the proliferation of books on Victorian religion alerts us to the possibility of reading the same religious phenomena differently. In Norman Vance's Bible \& Novel: Narrative Authority \& the Death of God (2013) and J. Russell Perkin's Theology and the Victorian Novel (2009), we get contrasting interpretations of work by Eliot, Hardy, and the theological impulses that led to the Broad Church. For Perkin, the more liberal explorations of the Christian religion offered by Eliot and Hardy constitutes a move away from orthodoxy, albeit one that remains of considerable interest for scholars interested in theological issues. By contrast, Vance sees such theological revision as being accommodated within the tradition rather than necessitating a break from it. In principle, Vance's claim is reasonable. His attempt to theorize his approach as postsecular is not as convincing as his subsequent readings of the Victorian novels he considers, in part because his 
engagement with the scholarship on the postsecular is limited, but this does not undermine his efforts to "reread secular Victorian fictions as modern narrative reimagingings of scriptural themes." ${ }^{5}$ One of the strengths of Vance's work is his insistence on the complexity and long history of the Christian tradition. Chapter 3 of his book is particularly helpful on historicizing the challenges to biblical authority in the nineteenth century, and he is right to chart how "the crude version of the Protestant narrative of the triumph of scriptural authority over Church tradition contained within it the seeks of its destruction, the emerging counter-narrative of partly misconceived scriptural authority approaching crisis and radical challenge" (6o). I am not entirely persuaded by his attempts to house Eliot and Hardy within the Christian faith, however: though I agree that their engagement with the Christian faith is extensive, and welcome Vance's suggestion that Hardy be understood as "post-Christian rather than anti-Christian" (116), the distinctions involved in claiming that Eliot "rebelled against the religion of her upbringing, but not, it can be argued, against God or the Bible" (92) seem forced. Vance's readings are theologically informed but his capacious account of what sort of revisions of the Christian faith might still be said to belong to that faith strike me as too relaxed, and I found myself sympathizing with those readers of Rider Haggard who, according to Vance, "did not always consciously realize the extent to which his quest narratives and intuitions of the sublime could represent an imaginative exploration of the 
things of the spirit and the nature of religious awareness which owed much to the Old Testament" (161).

Perkin is more willing to see a break between the novelists he considers and Christian theology, although this does not stop him from looking for ways of reading the authors he considers in conversation with theological writers and ideas. In the case of Hardy, Perkin argues, the "critique of theology and of liberal theology is written in the same kind of language as the discourses that are being attacked." 6 Perkin's chapter on Hardy is probably the strongest one in his book, and the suggestion towards the end of that chapter that Jude the Obscure be read as "the tragedy of the failure of the culture to live up to the promises Arnold made on its behalf' (191) is astute. Perkin is right to hone in on the influence of Matthew Arnold in seeking to modernize Christianity, and although Perkin is more cautious about this modernizing impulse than Vance, he shares the awareness that Christian discourse is fluid and that recognizing this allows one to connect the Victorian novel to a variety of different theological ideas. While Perkin's discussion is theologically sophisticated, some of his insights would benefit from being developed more boldly. The chapter on the implied theology of Vanity Fair is smart but overly cautious, and I am not sure that, when insisting that the novel "can be read within a frame of reference that transcends secularity" (15), we need the subsequent caveat that "If literature is to serve as a Jacob's ladder, however, I recognize that the novel is probably the bottom rung" (15). An older generation of critics may have felt that the 
novel was an inherently secular genre, but there is plenty in Perkin's thoughtful discussion that explains why this assumption no longer commands our loyalty.

One reason why scholars are able to read the same material so differently is the plurality of intellectual energy that has long been part of the Christian tradition, Christian theology has always been much less monolithic than literary scholars are prone to think, and the last few years have seen a number of religious historians reminding those of us in literary studies about religious debates within the church and among those influenced by it. Timothy Larsen's A People of One Book: The Bible and the Victorians (2011) offers an excellent example, employing a series of fascinating case studies to show the diverse uses to which the Bible was put in the period. Some of the figures Larsen reads, such as Charles Bradlaugh and T. H Huxley, continued to read the Bible carefully even though they saw themselves as having definitively moved on from the Christian faith. Others, such as Charles Spurgeon, Catherine Booth and Josephine Butler, identified as Christian but read scripture in assorted and sometimes opposing ways, reflecting the plurality of the Christian traditions in which they were immersed. Few figures in the nineteenth century epitomized the different interpretive options open to Christian believers more than John Henry Newman. He is mentioned on several occasions by Larsen but is not one of his case studies. But the plurality of Newman's engagement with the Christian tradition is brought out helpfully elsewhere, in Benjamin John King's 
historically sensitive study, Newman and the Alexandrian Fathers: Shaping Doctrine in Nineteenth-Century England (2009).

The influence of a rich and wide-ranging Christian tradition extended well beyond the lives of prominent individuals. Joseph Stubenrauch's astute and convincing The Evangelical Age of Ingenuity of Industrial Britain (2016) explores the dynamism of evangelical thought in the period, arguing for the movement's practical innovation in areas such as publishing and politics, and resisting the notion that evangelical was primarily a religion of the heart. And Frances Knight's recent contribution to our thinking about the theological life of theology at the end of century-Victorian Christianity at the Fin de Siècle: The Culture of English Religion in a Decadent Age (2015) — reveals the extent to which the vitality of Christian debates had practical consequences for vast swathes of Victorian culture. Rejecting the assumption that Christianity was in terminal decline by the end of the nineteenth century, Knight focuses her attention on how the Christian faith continued to exert an influence on the period, particularly in London. The first half of her book tracks the religious beliefs of several key figures in the late-nineteenth century and offers a series of helpfully nuanced historical details, including the scientific interests of several late-century Catholic converts. Thereafter, Knight's focuses on "the steady hum of religion in Britain's capital city."7 This approach reveals the extensive life of religious thought, from the Salvation Army's concern with social reform to the theological vision behind the creation of garden cities near the nation's capital. Yet 
Knight's readings in the second half of the book become looser and less-theologically specific. This is an inevitable consequence of her decision to think about Christianity less as "a doctrinal category" and more "as the religious culture created by those who were members of the major Christian denominations" (4), and is not necessarily a bad thing. Knight is better equipped than most to register the ongoing influence of theological ideas, and there are several moments in the book when she consciously addresses the consequences of some nineteenth-century thinkers moving to a vaguer account of what religion might mean. In the case of Richard La Gallienne's The Religion of a Literary Man (1893), for instance, Knight explains: "He was scathing about doctrine, the church and organised worship, but he wanted to retain Christianity, or what he termed the spiritual sense, which he voiced in Christian language, because he saw the alternative as narrow-minded, unimaginative materialism" (6o). But Knight's decision to focus on the cultural influence of Christianity and extend the boundaries of religious faith beyond those construed narrowly by secularism runs the risk of describing activities that involved members of the church but might, to an untrained eye, seem as likely to have been conducted by those with little or no allegiance to the Christian faith.

Historians are not alone in drawing attention to the complex historical map of Victorian Britain. Miriam Elizabeth Burstein's Victorian Reformations: Historical Fiction and Religious Controversy, 1820-190o (2014) does a tremendous job of exploring and complicating the theological debates mediated through historical 
fiction. Focusing on the narratives that Victorians told about the Reformation, about a time when the Protestant return to biblicism was alleged to have overcome the corruption of the Roman Catholic Church, Burstein considers what these narratives tell us about the religious concerns of the nineteenth century. Her study includes canonical novelists such as Dickens but also a host of other fiction writers, longsince forgotten, who played "a crucial role in nineteenth-century popular religious and literary cultures." ${ }^{8}$ A good number of these authors were evangelical, and Burstein interrogates their reasons for writing. As she explains, they "did not simply read the Reformation as an allegory, or analogy for Victorian cultural and religious controversies" but instead "fictionalize[d] Reformations crises so that the reader may learn to recognize that the present threatens to repeat the worst aspects of the past" (16-17). For many of the writers Burstein discusses, controversial historical fiction was the means of linking past and present, granting greater theological-historical significance to events unfolding in the nineteenth century. Some of these developments, such as the growing legitimacy of Roman Catholicism, were obviously troubling to evangelicals who consolidated their religious identity through opposition to the Church of Rome, Others proved troubling in more surprising ways. In a particularly stimulating chapter on the consequences on Bible reading of the Protestant ascendency in the nineteenth century, Burstein explores how evangelical novelists such as Emma Marshall, Elizabeth Rundle Charles, and Charles Bruce "urge their readers to remember the shock of Bible reading in the sixteenth century in 
order to estrange them from the Bible's boring omnipresence in the nineteenth century" (110).

One sees related efforts to read past and present simultaneously in Michael Wheeler's informative and remarkably knowledgeable book, St John and the Victorians (2012). While Wheeler's approach lacks the theoretical and polemical energy that marks Burstein's work, he is similarly committed to working through the ways in which Christian theology is understood differently across time and place. Leaning on the methodology adopted by those who work in biblical reception history, Wheeler's book offers an impeccably researched "study of the cultural afterlife of the fourth gospel in Victorian Britain" (xiii), and focuses on particular rereadings of texts from the Gospel of John, including the prologue, the story of the woman at the well, the raising of Lazarus, Mary's experience at the foot of the cross, and the encounters of Jesus's followers with his resurrected body. The strength of Wheeler's writing lies in his careful historical detail and extensive familiarity with a wide array of primary works; he is generally less interested, however, in developing a particular line of argument and/or mapping his investigations onto the work of recent literary scholarship.

One of the ideas to emerge most strongly from Wheeler's book is the extent to which biblical text pervaded all areas of Victorian culture. Charles LaPorte's reading in Victorian Poets and the Changing Bible (2011) of the reception of scripture in the Victorian era is similarly attuned to this point, although he offers a stronger 
line of argument than Wheeler. LaPorte traces the influence of higher criticism on some of the major Victorian poets, and makes a persuasive claim for thinking about poetic responses to the changing Bible in relation to the mythic dimension of higher criticism. Although the higher critics were better known for their emphasis on historicity and a more pseudo-scientific approach to the study of scripture, Romantic ideas about the role of myth in religious thought pervade their writing and lent themselves to a mode of biblical interpretation that was no longer dominated by the teaching of the church. LaPorte's careful reading of figures such as David Friedrich Strauss reminds us how the higher critics were less rigidly scientific in their mode of reading than we usually acknowledge and well aware that "true histories must always be mediated by a literary imagination." 9 This insight proved generative for several Victorian poets, even though their thoughts about the higher critics were often mixed. Elizabeth Barrett Browning thought "the higher criticism incapable of furnishing a true view of divine scriptures-even very new ones. And yet her own conception of poetry clearly derives from the hermeneutic revolution that produced the higher criticism..." (24). Tennyson also had conflicted thoughts about the ideas put forward by Benjamin Jowett, the most famous of the contributors to Essays and Reviews (1860). And in the case of Arthur Hugh Clough, the complex inheritance of the higher critics by Victorian poets is encapsulated nicely in LaPorte's arresting account of how “'Easter Day' and 'Easter Day II' are 
clearly intended to experiment with different ways of seeing the tradition of Strauss and Schleiermacher" (120-21).

While LaPorte's reading of the higher critics is original and persuasive, the strength of his book as a whole lies in the reading of Victorian poetry more than its engagement with theology. Comparatively little space is given over to theological voices after the introductory chapter, and there are a couple of occasions where his account of more conservative expressions of theology lacks the nuance that characterizes the rest of the book. LaPorte's work elsewhere makes it abundantly clear that he is highly conversant across multiple areas of theology, and my suspicion is that the relative lack of theological engagement in parts of Victorian Poets and the Changing Bible reflects the methodological preferences of the training in Victorian literature that many of us have received. This suspicion is borne out by Kirstie Blair's Form and Faith in Victorian Poetry and Religion (2012), which, like LaPorte, insists on the link between religious thought and poetic form but seems more comfortable talking about the latter than it does in discussing the former. Blair's readings of writers such as John Keble, Elizabeth and Robert Browning, Lord Alfred Tennyson and Gerard Manley Hopkins are enlightening, and while the premise of Blair's argument is relatively straightforward—steady and regular rhythms are commonly used to convey faith, whereas poetry that speaks of doubt is "more likely to deploy irregular, unsteady, unbalanced rhythms" — the book as a whole offers a rich and rewarding study..$^{10}$ Yet Blair rarely grants theology much 
explanatory force. In light of this, it is productive to read her book alongside Karen Dieleman's Religious Imaginaries: The Liturgical and Poetic Practice of Elizabeth Barrett Browning, Christina Rossetti, and Adelaide Procter (2012). Dieleman's argument is less polished than Blair's, but it does a really good job of engaging with theological resources and using them to tease out some of the ways in which we might think about the effect of Christian ecclesial practices, from preaching to liturgy, on the poetry of the period.

As the studies above attest, it can be hard to keep theology and literature in dialogue, not because of a deep fault line between the disciplines but because attending to both involves working across different discourses. Promising steps forward in this regard can be found in recent single-author studies, such as Duc Dau's thoughtful and provocative book, Touching God: Hopkins and Love (2012) and Elizabeth Ludlow's judicious study, Christina Rossetti and the Bible: Waiting with the Saints (2014). Relieved of the burden of making broader claims about Victorian poetry as a whole, Dau and Ludlow move fluently between theology and literature. The fact that they do so in very different ways testifies to the methodological richness of theology as a conversation partner for literary studies of Victorian poetry. Future work in this area will benefit enormously from the recent publication of Michael Hurley's wonderful new book, Faith in Poetry: Verse Style as a Mode of Religious Belief (2017). With chapters on Blake, Tennyson, Christina Rossetti, Hopkins and T. S. Eliot, Hurley's captivating and arresting study of the theological 
implications of style, in the authors he reads and also his own writing, stakes out the productive possibilities of writing about Victorian poetry in a way that keeps both religious and literary forms firmly in the forefront of our thinking.

While less attention has been paid in recent years to the theological implications of Victorian prose forms, this is not entirely surprising given the longstanding tendency for studies of poetry to pay closer interest to matters of form. And it would be wrong to conclude that studies of religion and Victorian prose are somehow at a less developed stage. At the forefront of recent scholarship is JanMelissa Schramm's Atonement and Self-Sacrifice in Nineteenth-Century Narrative (2012). Focusing on novels by Edward Bulwer Lytton, Charles Dickens, Elizabeth Gaskell, George Eliot and Anthony Trollope, Schramm explores the influence of a theological idea—the atonement—across Victorian literary culture and focuses in on the way in which the sacrifice at the heart of the doctrine of the atonement was taken up in the ethical concerns of Victorian novelists. Schramm's argument is theologically sophisticated, historically detailed, and textually suggestive, and her readings offer a compelling exploration of what "it means to 'live' in another (in the act of reading, this is the sympathetic process by which we change places with another, acquiring thereby vicarious experience), to 'stand for' another in the courtroom or in the House of Commons ..., to 'die for' another in theological terms ..., and finally to fraudulently 'pass oneself off as another' for financial gain..."1 Schramm's work has major implications for our histories of the novel, particularly in 
the light that it sheds on the theological ideas that shape so many Victorian narratives.

Ilana M. Blumberg's Victorian Sacrifice: Ethics and Exchange in Mid-Century Novels (2013) complements Schramm's book well. Blumberg's emphasis is on ethics more than theology, but she is impressively alert to the theological significance of the ethical debates she examines, and her intricate and lucid reading of novels such as A Tale of Two Cities, Adam Bede, The Moonstone and Robert Elsmere are valuable to anyone wondering how to map religious ideas onto broader debates about the Victorian novel. A related interest in the religious-ethical concerns of Victorian literature is also evident in Richard Gibson's Forgiveness in Victorian Literature: Grammar, Narrative and Community (2015). Gibson does not restrict his study to fiction, but this is the form that looms largest in his assured and perceptive study, and his readings of work by novelists such as Dickens, Trollope, Eliot and Hardy are sharp and full of insight. Another key work for those interested in thinking about religion in the context of the Victorian novel is Susan E. Colon's Victorian Parables (2012). As with Blumberg and Gibson, ethics offers Colon a theoretical route in, and she deftly juxtaposes a range of critical reading in biblical studies, the Victorian novel, and literature and ethics, to think about how parables work in Victorian fiction. As Colon explains, parables are a complex form that invites the reader into the story described before seeking to disrupt their overly settled and hypocritical views as to how one should live. Although parables are best known as a short form, 
Colon makes a compelling case for their relevance to the longer form of the novel, and builds on her theoretical foundation by offering shrewd readings of novels by Yonge, Oliphant and Dickens.

The shorter forms of fiction favored by many writers of the Victorian ghost story are explored by Zoe Lehmann Imfeld and Jan Cadwallader in their respective books, The Victorian Ghost Story and Theology: From Le Fanu to James (2016) and Spirits and Spirituality in Victorian Britain (2016). Challenging "the presumption that the supernatural tale lifts a veil only to a void, absent of theological ontology" Lehmann Imfeld considers instead how the writers she considers "sought to reaffirm Christian orthodoxy while at once reinstating the role of medieval mysticism to religious experience. ${ }^{12}$ Her engaging study is stronger on theology than it is on existing debates within literary studies, but the book has much to offer literary scholars working in this area, and does a good job of fulfilling its goal to "rediscover the theological language of the tales for today's readers" (6). Cadwallader's study is also intellectually rich, though its strengths are very different than Lehmann Imfeld's. Cadwallader's reading of particular authors is illuminating, and she makes some valuable links to the medical humanities in chapters that deal with madness and sexuality in Oliphant and Broughton, and spectral phenomena in the work of Le Fanu. But if the Victorian ghost story is, as Cadwallader claims, "a useful index of the shifting fortunes of faith over the century," then one struggles to see much theological possibility by the end of the Victoria era, not because of an intrinsic 
divide between religion and science, nor because Cadwallader sets out to make a case for secularization—indeed, "the afterlife," she argues, "was a space science and theology were hesitant to colonize during the nineteenth century"-but because the religious realm slips increasingly out of view as her book goes on. ${ }^{13}$

By contrast, religious ideas and practices are clearly in view throughout Joshua King's groundbreaking book, Imagined Spiritual Communities in Britain's Age of Print (2015). Taking a cue from Benedict Anderson's work on Imagined Communities but resisting his "implication that imagining national communities is an essential secular activity coordinated with the decay of religious forms of imagined community," King explores the ways in which the rise of print culture in the nineteenth century enabled new forms of spiritual community. ${ }^{14}$ In a chapter on John Keble's The Christian Year, for instance, King examines the way in which Keble's cultivation of "typological habits of mind" (139) brought Christians together across the boundaries of time and space. Rather than presuming that individual reading can only be understood within a narrative of secularization where belief is privatized, King shows how the drive towards individualism in modernity also had the effect of spurring new forms of religious community, through print culture, and, as he touches on in a suggestive concluding chapter, the digital age of the twentyfirst century. King's intellectual energy makes for a stimulating read from start to finish, and he is adept at reading a range of genres and authors. Alongside thoughtful readings of Keble, Tennyson, Arnold, and Christina Rossetti, King brings 
theological voices into his discussion in meaningful and evocative ways. One of the central figures in the story he tells is the important nineteenth-century theologian, F. D. Maurice. "Like Anderson," King explains, "Maurice stresses the decisive role played by modern media, such as novels and newspapers, in forming a sense of national community. Unlike Anderson, he does not see this formation as essentially secular or secularizing" (86). Though alert to Maurice's faults, including his paternalism, King is sympathetic to his vision of the role that the Anglican Church might play in enabling a more universal society. But as King observes, by the end of the century the diversification of religious belief and publishing activity, an emergent international context, and a wider move away from people expressing faith primarily in the context of church, made it increasingly hard for thinkers to continue Maurice's vision for the allegiance of religion and nationhood. These developments were not necessarily secular, though, with King arguing persuasively for the way in which "readers became adept at imagining themselves in or between far-flung spiritual communities shared with strangers" (289).

King is good at registering the different valences of words such as religion, Christianity and spiritual. His chapter on In Memoriam works through the consequences of Tennyson's minimum of faith, "an intuitive belief in God and immortality in the bedrock of the soul" (189), and helps us see the possibilities and limits of loosening the doctrinal specificity that we might otherwise associate with the Christian faith. Tennyson's approach in this respect-as with different thinkers 
such as Matthew Arnold—has tended to find favor with literary critics who want to take religion outside the boundaries of a Christian faith they think of as overly confining. But minimal definitions of faith are not the only means of opening up a wider conversation. As Julie Melynk and Alisa Clapp-Itnyre note in their introduction to a useful and lively collection of essays on different religious ideas of the period, "Protestantism remained dominant ... [but] Victorian England was not a religiously-homogenous nation." ${ }^{15}$ The heterogeneity of religion was evident within British Christianity. In addition to the distinctions between Protestantism and the Roman Catholicism that animated so much intellectual life as the century went on, the differences between the Church of England and dissent point to a Protestantism that was similarly contested and diverse. So many of the developments routinely taken as signs of secularization can be attributed to the influence and vitality of dissent. For example, the creation of University College London in 1826 involved the support of prominent Dissenters, Roman Catholics and Jews, as well as agnostics and atheists. This piece of information gives us a very different impression of the organization's initial relationship to religion than we might get from taking subsequent talk of its secular origins at face value.

The last decade has rightly seen a call to think about the role played by other religious traditions in the nineteenth century. I recognize that my use of the term "other" here is awkward, but it is hard to deny the primacy that Christianity, in all its varieties, had in Victorian Britain. And there is no neutral language through which 
one might talk about any of the world's major religions and avoid a prejudicial starting point. Rather than trying to neutralize difference by avoiding all talk of otherness, then, it is better to acknowledge one's starting point and move from here to an exploration of different perspectives. Understanding the role played by other religious traditions in the nineteenth-century has been made considerably easier by the appearance of key scholarly works, which not only give shape to the traditions concerned but also offer alternate jumping-off points for subsequent work on Victorian religion and literature. These works include J. Jeffrey Franklin's The Lotus and the Lion: Buddhism and the British Empire (2008). Rightly acclaimed for his historical insight about the reception of Buddhism in Britain, and, more generally, his attention to the religious syncretism that was so popular in late-nineteenth century writers such as Marie Corelli and Rider Haggard in particular, Franklin's book shows how the impossibility of thinking about Buddhism outside our western context does not need to stop us from engaging extensively with its proponents, sources and ideas.

We currently lack a similarly authoritative account of the role played by Hinduism, Islam or Sikhism in Victorian literature, although there some good articles in these areas, helpful material on Islam in Shahin Kuli Khan Khattak's Islam and the Victorians: Nineteenth-Century Perceptions of Muslim Practices and Beliefs (2008), and an excellent related historical study in J. Barton's Scott book, Spiritual Despots: Hinduism and the Genealogies of Self-Rule (2016). Judaism and Victorian 
literature has received more attention, with a number of scholars building on the valuable tradition of scholarship offered by Brian Cheyette $(1993,1996)$, Michael Ragussis (1995), Cynthia Scheinberg (2002), and Nadia Valman (2007). Recent studies include Heidi Kaufman's English Origins, Jewish Discourse and the Nineteenth-Century British Novel: Reflections on a Nested Nation (2009), Eitan BarYosef and Nadia Valman's collection, The Jew in Late-Victorian and Edwardian Culture: Between the East End and East Africa (2009), Naomi Hetherington and Nadia Valman's collection, Amy Levy: Critical Essays (2010), and Richa Dwor's Jewish Feeling: Difference and Affect in Nineteenth-Century Jewish Women's Writing (2015). In the last of these, Dwor traces a Jewish feeling that, though hard to pin down, was important to a number of writers in the nineteenth century and evident throughout their work. Intelligently weaving together theology, literature, theoretical work on affect, and nineteenth-century history, Dwor writes insightfully about Grace Aguilar, George Eliot and Amy Levy, highlighting a strand of nineteenth-century religious writing that is distinct from (yet as rich as) the various strands of thought that others have found in the Christian tradition.

While the preceding discussion might be taken to imply that studies of Christianity and Victorian literature are well served and that it is only the other major world religions that remain in need of further work, that is certainly not my intention. The last decade has been exciting time for the study of religion, and the appropriate response to the sheer scale of religious belief and practice in the period 
is to continue thinking about different religions, Christian and otherwise. This might include methods of study borrowed from comparative religion, with its desire to find parallels across different traditions, but this approach should not be seen as intrinsically preferable. The search for parallels and shared patterns can risk the erasure of religious particularity, and my hope is that future work will continue to consider the specificities and details of particular religious beliefs and practices, in all their various forms.

${ }^{1}$ Fish, "One University Under God?," C1.

${ }^{2}$ For a more recent example of this preference for doubt over faith, see Lane, The Age of Doubt (2011).

3 Wheeler, St John and the Victorians, 152.

${ }^{4}$ Levine, Forms, 17.

5 Vance, Bible \& Novel, 29.

${ }^{6}$ Perkin, Theology and the Victorian Novel, 161.

7 Knight, Victorian Christianity at the Fin de Siècle 117.

${ }^{8}$ Burstein, Victorian Reformations, 2.

9 LaPorte, Victorian Poets and the Changing Bible, 156.

${ }^{10}$ Blair, Form and Faith, 1.

${ }^{11}$ Schramm, Atonement and Self-Sacrifice, 34.

${ }^{12}$ Imfeld, The Victorian Ghost Story and Theology, 3, 4.

${ }^{13}$ Cadwallader, Spirits and Spirituality, 3, 139.

${ }^{14}$ King, Imagined Spiritual Communities, 4.

${ }^{15}$ Julie Melynk and Alisa Clapp-Itnyre, "Introduction," in Melynk and Clapp-Itnyre, eds., Perplext in Faith," 3.

\section{Bibliography}

Agamben, Giorgio. Pilate and Jesus. Trans. Adam Kotsko. Stanford: Stanford University Press, 2015. 
. The Time That Remains: A Commentary on the Letter to the Romans.

Trans. Patricia Dailey. Stanford: Stanford University Press, 2005.

Blair, Kirstie. Form and Faith in Victorian Poetry and Religion. Oxford: Oxford University Press, 2012.

Blumberg, Ilana M. Victorian Sacrifice: Ethics and Exchange in Mid-Century Novels. Columbus, OH: Ohio State University Press, 2013.

Burstein, Miriam Elizabeth. Victorian Reformations: Historical Fiction and Religious Controversy, 1820-190o. South Bend, IN: University of Notre Dame Press, 2014.

Butler, Judith. Precarious Life: The Powers of Mourning and Violence. New York: Verso, 2004 .

Bar-Yosef, Eitan and Nadia Valman, eds. The Jew in Late-Victorian and Edwardian Culture: Between the East End and East Africa. London: Palgrave Macmillan, 2009.

Cadwallader, Jan. Spirits and Spirituality in Victorian Britain. New York: Palgrave Macmillan, 2016.

Cheyette, Brian. Construction of "the Jew" in English Literature and Society: Racial Representations 1875-1945. Cambridge: Cambridge University Press, 1993.

Cheyette, Brian, ed. Between "Race" and Culture: Representations of "the Jew" in English and American Literature. Stanford: Stanford University Press, 1996.

Clapp-Itnyre, Alisa and Julie Melynk, eds. "Perplext in Faith": Essays on Victorian Beliefs and Doubts. Cambridge: Cambridge Scholars Publishing, 2015. 
Colon, Susan E. Victorian Parables. London: Bloomsbury, 2012.

Cunningham, Valentine. Everywhere Spoken Against: Dissent in the Victorian Novel. Oxford: Clarendon Press, 1975.

Dau, Duc. Touching God: Hopkins and Love. London: Anthem Press, 2012.

Derrida, Jacques. Acts of Religion. Ed. Gil Anidjar. New York: Routledge, 2002.

Dieleman, Karen. Religious Imaginaries: The Liturgical and Poetic Practice of Elizabeth Barrett Browning, Christina Rossetti, and Adelaide Procter. Athens, OH: Ohio University Press, 2011.

Dwor, Richa. Jewish Feeling: Difference and Affect in Nineteenth-Century Jewish Women's Writing. London: Bloomsbury, 2015.

Fish, Stanley. “One University Under God?” The Chronicle of Higher Education 51.18 (January 7,2005$)$.

Franklin, J. Jeffrey. The Lotus and the Lion: Buddhism and the British Empire. Ithaca: Cornell University Press, 2008.

Gibson, Richard. Forgiveness in Victorian Literature: Grammar, Narrative and Community. London: Bloomsbury, 2015.

Hanson, Ellis. Decadence and Catholicism. Cambridge, MA: Harvard University Press, 1997.

Hetherington, Naomi and Nadia Valman, eds. Amy Levy: Critical Essays. Athens, OH: Ohio University Press, 2010. 
Hervieu-Léger, Danièle. Religion as a Chain of Memory. New Jersey: Rutgers University Press, 2001.

Hurley, Michael. Faith in Poetry: Verse Style as a Mode of Religious Belief. London: Bloomsbury, 2017.

Imfeld, Zoe Lehmann. The Victorian Ghost Story and Theology: From Le Fanu to James. Switzerland: Palgrave Macmillan, 2016.

Jager, Colin. The Book of God: Secularization and Design in the Romantic Era. Philadelphia: University of Pennsylvania Press, 2006.

Jay, Elisabeth. The Religion of the Heart: Anglican Evangelicalism and the NineteenthCentury Novel. Oxford: Clarendon Press, 1979.

Kaufman, Heidi. English Origins, Jewish Discourse, and the Nineteenth-Century British Novel: Reflections on a Nested Nation. University Park: Pennsylvania State University Press, 2009.

Khattak, Shahin Kull Khan. Islam and the Victorians: Nineteenth Century Perceptions of Muslim Practices and Beliefs. London: I. B. Tauris, 2008.

King, Benjamin John. Newman and the Alexandrian Fathers: Shaping Doctrine in Nineteenth-Century England. Oxford: Oxford University Press, 2009.

King, Joshua. Imagined Spiritual Communities in Britain's Age of Print. Columbus, OH: Ohio State University Press, 2015.

Knight, Frances. Victorian Christianity at the Fin de Siècle: The Culture of English Religion in a Decadent Age. London: I. B. Tauris, 2015. 
Knight, Mark and Emma Mason. Nineteenth-Century Religion and Literature: An Introduction. Oxford: Oxford University Press, 2006.

Krueger, Christine. The Reader's Repentance: Women Preachers, Women Writers, and Nineteenth-Century Social Discourse. Chicago: University of Chicago Press, 1992.

Landow, George. Victorian Types, Victorian Shadows: Biblical Typology and Victorian Literature, Art, and Thought. London: Routledge, 1980.

Lane, Christopher. The Age of Doubt: Tracing the Roots of Our Religious Uncertainty. New Haven: Yale University Press, 2011.

LaPorte, Charles. Victorian Poets and the Changing Bible. Charlottesville: University of Virginia Press, 2011.

Larsen, Timothy. A People of One Book: The Bible and the Victorians. Oxford: Oxford University Press, 2011.

Latour, Bruno. Rejoicing: Or the Torments of Religious Speech. Trans. Julie Rose. London: Polity, 2013.

Levine, Caroline. Forms: Whole, Rhythm, Hierarchy, Network. New Jersey: Princeton University Press, 2015.

Ludlow, Elizabeth. Christina Rossetti and the Bible: Walking with the Saints. London: Bloomsbury, 2014.

Mahmood, Saba, Talal Asad, Wendy Brown, and Judith Butler. Is Critique Secular? Blasphemy, Injury and Free Speech. New York: Fordham University Press, 2011. 
Maynard, John. Victorian Discourses on Sexuality and Religion. Cambridge: Cambridge University Press, 1993.

McKelvy, William. The English Cult of Literature: Devoted Readers, 1774-188o. Charlottesville: The University of Virginia Press, 2007.

Miller, J. Hillis. The Disappearance of God: Five Nineteenth-Century Writers. Urbana: University of Illinois Press, 1963.

O’Malley, Patrick R. Catholicism, Sexual Deviance and Victorian Gothic Culture. Cambridge: Cambridge University Press, 2006.

Oulton, Carolyn W. de la L. Literature and Religion in Mid-Victorian England: From Dickens to Eliot. Basingstoke: Palgrave Macmillan, 2003.

Prickett, Stephen. Words and The Word: Language, Poetics and Biblical Interpretation. Cambridge: Cambridge University Press, 1986.

Perkin, J. Russell. Theology and the Victorian Novel. Montreal and Kingston: McGillQueen’s University Press, 2009.

Ragussis, Michael. Figures of Conversion: "The Jewish Question" and English National Identity. Durham, NC: Duke University Press, 1995.

Roden, Frederick S. Same-Sex Desire in Victorian Religious Culture. Basingstoke: Palgrave Macmillan, 2002.

Schad, John. Queer Fish: Christian Unreason from Darwin to Derrida. Brighton: Sussex Academic Press, 2004. 
Scheinberg, Cynthia. Women's Poetry and Religion in Victorian England: Jewish Identity and Christian Culture. Cambridge: Cambridge University Press, 2002.

Schramm, Jan-Melissa. Atonement and Self-Sacrifice in Nineteenth-Century Narrative. Cambridge: Cambridge University Press, 2012.

Scott, J. Barton. Spiritual Despots: Modern Hinduism and the Genealogies of Self-Rule. Chicago: University of Chicago Press, 2016.

Stubenrauch, Joseph. The Evangelical Age of Ingenuity of Industrial Britain. Oxford: Oxford University Press, 2016.

Taylor, Charles. A Secular Age. Cambridge, MA; Harvard University Press, 2007.

Tennyson, G. B. Victorian Devotional Poetry: The Tractarian Mode. Cambridge, MA: Harvard University Press, 1981.

Valman, Nadia. The Jewess in Nineteenth-Century British Literary Culture. Cambridge: Cambridge University Press, 2007.

Vance, Norman. Bible \& Novel: Narrative Authority \& the Death of God. Oxford: Oxford University Press, 2013.

"Victorian Religion." Special Issue of Victorian Literature and Culture 31.3 (2003).

Wheeler, Michael. The Old Enemies: Catholic and Protestant in Nineteenth-Century English Culture. Cambridge: Cambridge University Press, 2007. . St John and the Victorians. Cambridge: Cambridge University Press, 2012.

Zizek, Slavoj. The Fragile Absolute or Why is the Christian Legacy Worth Fighting For? London: Verso, 2000. 
